\title{
Effects of Maternal Socioeconomic, Psychological, Nutritional Factor, and Ambient Smoke Exposure, on the Risk of Low Birth Weight: A Multilevel Evidence from Gunungkidul, Yogyakarta
}

\author{
Isne Susanti'), Harsono Salimo²), Yulia Lanti Retno Dewi3) \\ 1)Masters Program in Public Health, Universitas Sebelas Maret \\ 2)Department of Pediatrics, Dr. Moewardi Hospital, Surakarta \\ 3)Department of Nutrition, Faculty of Medicine, Universitas Sebelas Maret
}

\section{ABSTRACT}

Background: Low birth weight (LBW) is one of the main causes of infant mortality. Globally, 2.5 million infants die in the first month after birth, and about 1 million die in the first day of birth. This study aimed to determine the biopsychosocial and contextual factors of community health centers that cause low birth weight in Gunungkidul Regency, Special Region of Yogyakarta, Indonesia.

Case Report: This case-control study was conducted at 25 community health centers in Gunungkidul, Yogyakarta, Indonesia, from January to February 2020. A sample of 200 infants, consisting of 50 infants with LBW (case) and 150 infants with normal birth weight (control) was selected by simple random sampling. The dependent variable was low birth weight. The independent variables were maternal education, early marriage, family income, frequency of ANC visits, maternal age at pregnancy, household cigarette smoke exposure, gestational stress, anemia, and maternal nutritional status. Data were collected using medical records, maternal and child health books, and questionnaires. Data were analyzed using multiple multilevel logistic regression analysis.

Results: The risk of LBW increased with maternal age at pregnancy $<20$ years or $\geq 35$ years $(b=1.9 ; 95 \% \mathrm{CI}=0.01$ to $3.73 ; \mathrm{p}=0.050)$, cigarette smoke exposure $(\mathrm{b}=1.9 ; 95 \% \mathrm{CI}=0.33$ to $3.49 ; \mathrm{p}=0.018)$, high gestational stress $(\mathrm{b}=$ $1.8 ; 95 \% \mathrm{CI}=-0.01$ to $3.67 ; \mathrm{p}=0.050)$, and anemia $(b=3.1 ; 95 \% \mathrm{CI}=1.24$ to $4.90 ; \mathrm{p}=$ o.001). The risk of LBW decreased with maternal education $\geq$ Senior High School $(b=-1.8$; 95\% CI $=-3.14$ to $-0.53 ; \mathrm{p}=0.006$ ), family income $\geq \mathrm{Rp} 1,706,525(\mathrm{~b}=-2.6 ; 95 \% \mathrm{CI}=-3.94$ to -1.27; $\mathrm{p}<0.001$ ), and maternal MUAC $\geq 23.5 \mathrm{~cm}$ $(\mathrm{b}=-1.7 ; 95 \% \mathrm{CI}=-3.25$ to $-0.17 ; \mathrm{p}=0.029)$.

Conclusion: The risk of LBW increases with maternal age at pregnancy $<20$ years or $\geq 35$ years, cigarette smoke exposure, high gestational stress, and anemia. The risk of LBW decreases with maternal education $\geq$ Senior High School, family income $\geq \mathrm{Rp} 1,706,525$, and maternal $\mathrm{MUAC} \geq 23.5 \mathrm{~cm}$.

Keywords: biopsychosocial, contextual effect, low birth weight

\section{Correspondence:}

Isne Susanti. Masters Program in Public Health, Universitas Sebelas Maret. Jl. Ir. Sutami 36A, Surakarta 57126, Central Java. Email: isnesusanti@gmail.com. Mobile: +6285271128121.

Cite this as:

Susanti I, Salimo H, Dewi YLR (2020). Effect of Maternal Socioeconomic, Psychological, Nutritional Factors, and Ambient Smoke Exposure, on the Risk of Low Birth Weight: A Multilevel Evidence from Gunungkidul, Yogyakarta. J Matern Child Health. 05(04): 446-455. https://doi.org/10.26911/thejmch.2020.05.04.12.

c) (1) Journal of Maternal and Child Health is licensed under a Creative Commons Attribution-Non Commercial-Share Alike 4.o International License.

\section{BACKGROUND}

According to the World Health Organization (WHO), in 2017, globally, 2.5 million children died in the first month after birth. About 7000 newborns die each day, and about 1 million die on the first day of birth. The risk of death in children is highest during the neonatal period or within the first 28 days after birth. Neonatal mortality is closely related to the quality of delivery 
services and suboptimal handling of newborns immediately after birth and the first few days after birth. One of the main causes of death is the low birth weight (LBW) (World Health Organization, 2012).

Based on data from the 2012 IDHS (Indonesian Demography and Health Survey), the infant mortality rate (IMR) reached 32/100o live births. Data from the IDHS in 2017 stated that the trend of IMR decreased by $25 \%$ from 32 to $24 / 1000$ live births (Ministry of Health, 2018).

Based on the results of the Basic Health Research in 2018, although the quality and access to health are good, the proportion of Birth Weight <2500 grams (LBW) is still 6.2\% (Riskesdas, 2018). The prevalence rate of LBW in Yogyakarta in 2018 reached $5.52 \%$, and the prevalence rate of LBW in Gunung Kidul occupied the highest position reaching $7.15 \%$ in 2018 (DIY Health Office, 2019).

Based on data from the Health Profiles of Gunung Kidul Regency in 2018, the Infant Mortality Rate (IMR) is 10/1,000 live births. The number of deaths in 2017 has increased compared to 2016. The Infant Mortality Rate (IMR) is still relatively high in Gunung Kidul than other districts in the Special Region of Yogyakarta (DIY). The main causes of infant mortality are LBW, preterm birth, and asphyxia (DIY Health Office, 2019).

LBW is caused by many things. Based on a study conducted by Rajashree, Prashanth, and Revathy in 2015, the proportion of LBW is the mother's age during pregnancy, education, work, daytime rest during pregnancy, weight gain during pregnancy, and hemoglobin levels in mothers. Several trigger factors cause LBW, namely, biological factors, psychological factors, and socioeconomic factors (Mahumud, Sultana and Sarker, 2017).
Health center's accreditation is a recognition of a health center given by an independent accreditation agency set by the Minister after it has been assessed that the health center has met the health center service standards set by the Minister of Health to improve the quality of health center services on an ongoing basis. To improve service quality, health center must be accredited periodically at least once every three years (Ministry of Health, 2015).

\section{SUBJECTS AND METHOD}

\section{Study Design}

This was an analytic observational study with a case-control design. The study was conducted at 25 community health centers in Gunung Kidul, Yogyakarta, Indonesia, from January to February 2020.

\section{Population and Sample}

The target population was infants with LBW. The source population was infants with LBW in Gunung Kidul. A sample of 200 infants was divided into: (1) 50 infants with LBW (case) and 150 infants with normal birth weight (control). The study subjects were selected by simple random sampling.

In this study, there were exclusion criteria, namely, twins' delivery, mothers with mental disorders, mothers who do not live in Gunungkidul.

\section{Study Variables}

The dependent variable was low birth weight. The independent variables were maternal education, early marriage, family income, frequency of ANC visits, maternal age at pregnancy, cigarette smoke exposure, stress gestational stress, anemia, maternal nutritional status (mid-upper arm circumference/ MUAC).

4. Operational Definition of Variables Birth weight was measured when the baby was born within the first hour of birth, 
expressed in grams. The instruments used questionnaires, medical records, and $\mathrm{MCH}$ books. The measurement scale was continous, coded $\mathrm{O}=$ normal birth weight $(\geq 2,500$ gram $)$ and $1=$ low birth weight $(<2,500$ gram).

Maternal education status was the highest education that has been taken. Based on the possession of the last certificate at the time of the last pregnancy. The instruments used were questionnaires and the $\mathrm{MCH}$ book. The measurement scale was categorical, with code $\mathrm{O}=$ low (<senior high school) and $1=$ high ( $\geq$ senior high school).

Early marriage was marriage or union between two people in which one or both parties are younger than 19 years of age, which can pose health risks for women. The instrument used was a questionnaire. The measurement scale was continuous, and transformed into dichotomous, coded $0<19$ years and $1 \geq 19$ years.

Family income was the amount of income from the mother and husband expressed in rupiah. The instrument used was a questionnaire. The measurement scale was continous and transformed into dichotomous, coded $\mathrm{O}=$ low income $(<\mathrm{Rp}$ $1,706,525)$ and $1=$ high income $(\geq \mathrm{Rp}$ 1,706,525).

The frequency of ANC visits was the number of visits conducted by women during pregnancy to health personnel. The instruments used are questionnaire and the $\mathrm{MCH}$ book. The measurement scale was continous, coded $o \geq 9$ visits and $1<9$ visits.

Maternal age at pregnancy was length of the mother's life from birth to pregnancy. The instruments used were a questionnaire and the $\mathrm{MCH}$ book. The measurement scale was continous, coded $\mathrm{O}=\geq 20$ years to $<35$ years and $1=<20$ years, $\geq 35$ years.

Household cigarette smoke exposure was the frequency of exposure to cigarette smoke in pregnant women either as active or passive smokers. The instrument used was a questionnaire. The measurement scale used categorical data, with the code $\mathrm{O}=$ not exposed and $1=$ exposed.

Psychological stress during gestation was a feeling of depression due to changes in financial conditions, family problems, worries about moving places, losing something valuable, worries about pregnancy, physical, sexual and emotional abuse, problems in work and friendships, and a feeling of being too overwhelmed. The instrument used was a questionnaire. The measurement scale was categorical, coded $\mathrm{O}=$ low (score <20) and $1=$ high (score $\geq 20$ ).

Anemia was maternal condition in which the $\mathrm{Hb}$ level during pregnancy was below $<11 \mathrm{~g} / \mathrm{dl}$. The instrument used was the $\mathrm{MCH}$ book. The measurement scale used continous, coded $\mathrm{O}=$ no anemia $(\mathrm{Hb} \geq 11$ $\mathrm{g} / \mathrm{dl})$ and $1=$ anemia $(\mathrm{Hb}<11 \mathrm{~g} / \mathrm{dl})$.

Nutritional status (MUAC) was the condition of the maternal nutritional status during pregnancy, which was assessed based on the size of the upper arm circumference (MUAC). The instruments used were a questionnaire and the $\mathrm{MCH}$ book. The measurement scale was continous, code $\mathrm{O}=$ malnutrition (MUAC $<23.5 \mathrm{~cm}$ ) and $1=$ good nutrition (MUAC $\geq 23.5 \mathrm{~cm}$ ).

Health center contextual was assessed from the health center's accreditation status, which was affected by the availability and completeness of health supplies, facilities, and infrastructure that support health services at the health centers. The measurement scale was categorical, code $\mathrm{O}=$ not accredited, $\mathbf{1}=$ basic accredited, $2=$ middle accredited, $3=$ main accredited, and 4= fully accredited

\section{Data Analysis}

Sample characteristics were described by univariate analysis. The bivariate analysis using chi-square. Multivariate analysis used 
multivariate analysis to determine the effect of a variable from the independent variable and the dependent variable.

\section{Research Ethic}

Research ethics was included in the consent form, anonymously, and confidentiality. This study's ethical approval was conducted at Dr. Moewardi Hospital, Surakarta, Indonesia, No. 1.475/XII/HREC/2019.

\section{RESULTS}

\section{Sample Characteristics}

Table 1 shows that the early marriage variable had a mean $=\mathbf{2 1 . 8 8}$ with the lowest early marriage age was 17 years. Family income had a mean $=$ Rp. 1,706,525 and $\mathrm{SD}=$
Rp. 2,669,012, with the lowest family income, was Rp. 900,000. The frequency of ANC visits variable showed a mean $=11.04$ and $\mathrm{SD}=1.79$ with the lowest frequency of ANC visits, was five times. The maternal age variable at pregnancy had a mean= 27.33 and $\mathrm{SD}=5.58$ with the lowest maternal age at 18 years.

The average of cigarette smoke exposure score was 10.81 (Mean= 10.81; $\mathrm{SD}=$ 2.27). The mean score for psychological stress at gestation was 20.29 (Mean= 20,29; $\mathrm{SD}=1.52)$. The mean of maternal MUAC was $26.37 \mathrm{~cm}($ Mean= 26.37; $\mathrm{SD}=$ 2.92). The mean of birth weight was 2,800 grams (Mean= 2,858.77; $\mathrm{SD}=473.73)$.

Table 1. Univariate analysis (continuous data)

\begin{tabular}{lcccc}
\hline \multicolumn{1}{c}{ Variable } & Mean & SD & Min. & Max. \\
\hline Early marriage (years) & 21.88 & 2.39 & 17 & 29 \\
Family income (Rupiah) & $1,706,525$ & 266.9012 & 900,000 & 2,500, ooo \\
Frequency of ANC visits & 11.04 & 1.79 & 5 & 14 \\
Maternal age (years) & 27.33 & 5.58 & 18 & 47 \\
Cigarette smoke exposure & 10.81 & 2.27 & 10 & 19 \\
Psychological stress & 20.28 & 1.52 & 19 & 27 \\
MUAC (cm) & 26.37 & 2.92 & 21 & 33 \\
Birth weight (grams) & $2,858.77$ & 473.73 & 2, ooo & 4,840 \\
\hline
\end{tabular}

Table 2. Sample characteristics (dichotomous data)

\begin{tabular}{|c|c|c|}
\hline Variable & (n) & Percentage (\%) \\
\hline \multicolumn{3}{|l|}{ Maternal education } \\
\hline$<$ Senior High School & 57 & 28.5 \\
\hline$\geq$ Senior High School & 143 & 71.5 \\
\hline \multicolumn{3}{|l|}{ Early marriage } \\
\hline$<19$ years & 21 & 10.5 \\
\hline$\geq 19$ years & 179 & 89.5 \\
\hline \multicolumn{3}{|l|}{ Family income } \\
\hline Low $(<\operatorname{Rp} 1.706 .525)$ & 62 & 31.0 \\
\hline $\operatorname{High}(\geq \operatorname{Rp} 1.706 .525)$ & 138 & 69.0 \\
\hline \multicolumn{3}{|l|}{ Frequency of ANC visits } \\
\hline Complete ( $\geq 9$ times) & 177 & 88.5 \\
\hline Incomplete $(<9$ times $)$ & 23 & 11.5 \\
\hline \multicolumn{3}{|l|}{ Maternal age at pregnancy } \\
\hline$\geq 20$ years to $<35$ years & 172 & 86.0 \\
\hline$<20$ years to $\geq 35$ years & 28 & 14.0 \\
\hline \multicolumn{3}{|l|}{ Cigarette smoke exposure } \\
\hline Not exposed & 170 & 85.0 \\
\hline Exposed & 30 & 15.0 \\
\hline \multicolumn{3}{|l|}{ Gestational stress } \\
\hline Low stress & 179 & 89.5 \\
\hline High stress & 21 & 10.5 \\
\hline
\end{tabular}


Susanti et al./ Multilevel Evidence of Low Birth Wieight

\section{Anemia}

Not anemic

Anemic

Nutritional status (MUAC)

$<23.5 \mathrm{~cm}$ (malnutrition)

$\geq 23.5 \mathrm{~cm}$ (good nutrition)

\begin{tabular}{cc}
158 & 79.0 \\
42 & 21.0 \\
& \\
30 & 14.0 \\
170 & 85.0 \\
\hline
\end{tabular}

\section{The result of bivariate analysis}

Table 2 shows the data from the univariate analysis (dichotomous data) of 200 study subjects, which showed that mothers with maternal education have education $\geq$ Senior High School were 143 people (71.5\%). There were 179 mothers who did not marry early (89.5\%). Mothers who had high family income were 138 people (69.0\%). There were 177 mothers who had complete ANC visits ( $\geq 9$ times) (88.5\%). There were 172 mothers at the time of pregnancy aged $\geq \mathbf{2 0}$ to $<35$ years $(86.0 \%)$.

Mothers who were not exposed to household cigarette smoke exposure were 170 people (85.0\%). Mothers who experienced low gestational stress were 179 people (89.5\%). There were 158 mothers who did not experience anemia during pregnancy (79.0\%). There were 170 mothers who had MUAC $\geq 23.5 \mathrm{~cm}(85.0 \%)$.

Table 3 shows the risk of low birth weight decreased with higher education $(\mathrm{OR}=0.12 ; \mathrm{p}<0.001)$, being married at $\geq 19$ years of age $(\mathrm{OR}=0.16 ; \mathrm{p}<0.001)$, high family income $(\mathrm{OR}=0.06 ; \mathrm{p}<0.001)$, and good nutritional status (MUAC) $(\mathrm{OR}=0.07$; $\mathrm{p}<0.001$ ).

The risk of LBW increased with the frequency of $\mathrm{ANC}$ visits $<9$ times $(\mathrm{OR}=$ $3.99 ; \mathrm{p}=0.001$ ), maternal age at pregnancy $<20$ or $\geq 35$ years $(\mathrm{OR}=11.8 ; \mathrm{p}<0.001)$, cigarette smoke exposure $(\mathrm{OR}=4.5 ; \mathrm{p}=$ o.o01), high gestational stress $(\mathrm{OR}=6.2$; $\mathrm{p}<0.001)$, and anemia $(\mathrm{OR}=17.3 ; \mathrm{p}$ $<0.001)$.

Table 3. The results of the bivariate analysis with the Chi-Square test

\begin{tabular}{|c|c|c|c|c|c|c|}
\hline \multirow{3}{*}{ Independent variable } & \multicolumn{4}{|c|}{ Birth Weight } & \multirow{3}{*}{$\mathbf{O R}$} & \multirow{3}{*}{$\mathbf{p}$} \\
\hline & \multicolumn{2}{|c|}{$\begin{array}{c}\text { Normal birth } \\
\text { weight }\end{array}$} & \multicolumn{2}{|c|}{ LBW } & & \\
\hline & $\mathbf{N}$ & (\%) & $\mathbf{N}$ & (\%) & & \\
\hline \multicolumn{7}{|l|}{ Maternal education } \\
\hline <Senior High School & 26 & 45.6 & 31 & 54.4 & 0.12 & $<0.001$ \\
\hline$\geq$ Senior High School & 124 & 86.7 & 19 & $13 \cdot 3$ & & \\
\hline \multicolumn{7}{|l|}{ Early marriage } \\
\hline$<19$ years & 8 & 38.1 & 13 & 61.9 & 0.16 & $<0.001$ \\
\hline \multirow{2}{*}{\multicolumn{7}{|c|}{ Family income }} \\
\hline & & & & & & \\
\hline Low $(<\mathrm{Rp} 1.706 .525)$ & 24 & 38.7 & 38 & 61.3 & 0.06 & $<0.001$ \\
\hline High ( $\geq$ Rp1.706.525) & 126 & 91.3 & 12 & 8.7 & & \\
\hline \multicolumn{7}{|l|}{ Frequency of ANC visits } \\
\hline Complete ( $\geq 9$ times) & 139 & 78.5 & 38 & 21.5 & 3.99 & 0.001 \\
\hline Incomplete (<9 times) & 11 & 47.8 & 12 & 52.7 & & \\
\hline \multicolumn{7}{|l|}{ Maternal age at pregnancy } \\
\hline$\geq 20$ years to $<35$ years & 142 & 82.6 & 30 & 17.4 & 11.8 & $<0.001$ \\
\hline$<20$ years to $\geq 35$ years & 8 & 28.6 & 20 & 71.4 & & \\
\hline
\end{tabular}

3. The result of multivariate analysis

Table 4 shows the risk of low birth weight increased with maternal age at pregnancy
$<20$ years or $\geq 35$ years $(\mathrm{b}=1.9 ; 95 \% \mathrm{CI}=$ 0.01 to $3.73 ; \mathrm{p}=0.050$ ), exposure to cigarette smoke $(b=1.9 ; 95 \% \mathrm{CI}=0.33$ to 3.49 ; 
$\mathrm{p}=0.018)$, stress during gestation was high $(b=1.8 ; 95 \% \mathrm{CI}=-0.01$ to $3.67 ; \mathrm{p}=0.050)$, and the mother suffered from anemia $(b=$ $3.1 ; 95 \% \mathrm{CI}=1.24$ up to $4.90 ; \mathrm{p}=0.001$ ).

The risk of low birth weight decreased with maternal education $\geq$ Senior High School $(b=-1.8 ; 95 \% \mathrm{CI}=-3.14$ to $-0.53 ; \mathrm{p}=$ o.006), family income $\geq \mathrm{Rp} 1,706,525(\mathrm{~b}=$ 2.6; 95\% CI= -3.94 to -1.27 ; $\mathrm{p}=0.000$ ), and nutritional status (MUAC) $\geq 23.5 \mathrm{~cm}(\mathrm{~b}=$ 1.7; 95\% CI= -3.25 to $-0.17 ; \mathrm{p}=0.029)$.

There was a contextual effect of the health center on the incidence of LBW with ICC $=25 \%$. This indicator shows that it was in accordance with the rule of thumb 8$10 \%$, whereas the condition of the health center at each level had a different effect, so it was an important factor.

\section{Table 4. Multilevel multiple logistic regression analysis}

\begin{tabular}{|c|c|c|c|c|}
\hline \multirow[b]{2}{*}{ Independent Variable } & \multirow{2}{*}{$\begin{array}{l}\text { Regression } \\
\text { coefficient } \\
\text { (b) }\end{array}$} & \multicolumn{2}{|c|}{$95 \% \mathrm{CI}$} & \multirow[b]{2}{*}{$\mathbf{p}$} \\
\hline & & $\begin{array}{l}\text { Lower } \\
\text { limit }\end{array}$ & $\begin{array}{c}\text { Upper } \\
\text { limit }\end{array}$ & \\
\hline \multicolumn{5}{|l|}{ Fixed Effect } \\
\hline Maternal education ( $\geq$ Senior High School) & -1.8 & -3.14 & -0.53 & 0.006 \\
\hline Family income $(\geq \mathrm{Rp} 1,706,525)$ & -2.6 & -3.94 & -1.27 & $<0.001$ \\
\hline $\begin{array}{l}\text { Maternal age at pregnancy }(<20 \text { years, } \geq 35 \\
\text { years) }\end{array}$ & 1.9 & 0.00 & 3.73 & 0.050 \\
\hline Household cigarette smoke (exposed) & 1.9 & 0.33 & 3.49 & 0.018 \\
\hline Psychological stress during gestation (high) & 1.8 & -0.00 & 3.67 & 0.050 \\
\hline Anemia & 3.1 & 1.24 & 4.90 & 0.001 \\
\hline Nutritional status (MUAC) $(\geq 23.5 \mathrm{~cm})$ & -1.7 & -3.25 & -0.17 & 0.029 \\
\hline \multicolumn{5}{|l|}{ Random Effect } \\
\hline Health centers & 1.13 & 0.087 & 14.82 & \\
\hline $\mathrm{N}$ observation & 200 & & & \\
\hline \multicolumn{5}{|l|}{$\mathrm{N}$ group $=25$} \\
\hline \multicolumn{5}{|l|}{ Group average $=8$} \\
\hline \multicolumn{5}{|l|}{$\operatorname{Min}=8, \operatorname{Max}=8$} \\
\hline \multicolumn{5}{|l|}{ Log likelihood $=-43.12$} \\
\hline $\mathrm{p}<0.001$ & & & & \\
\hline $\mathrm{ICC}=25 \%$ & & & & \\
\hline
\end{tabular}

\section{DISCUSSION}

1. The effect of maternal education on the incidence of $\mathrm{LBW}$

The results of this study indicate that there is an effect of maternal education on the incidence of LBW. Mothers with education $\geq$ Senior High School have the possibility (logodd) to experience LBW 1.8 units less than mothers with <Senior High School education.

The results of this study are also in line with a study conducted by Sebayang et al., 2012 which stated that mothers who only have basic education have the possibility to increase the risk of giving birth to a child with LBW by 1.62 times than mothers who have higher education.

Maternal education, in general, can affect a healthy lifestyle and health care process. Mothers with tertiary education may also be at risk for low birth weight babies. This finding occurs in mothers with higher education because it is related to maternal employment status. Women with higher education can have jobs with more stress that give birth to unnatural births. Previous studies have shown that pregnant women who experience stress are a significant risk factor for the incidence of low birth weight babies (Islam and ElSayed, 2015). 


\section{The effect of family income on the incidence of $\mathrm{LBW}$}

This study indicates that there is an effect of family income on the incidence of LBW. Mothers with family income $\geq \mathrm{Rp} 1,706,525$ have the possibility (logodd) to experience the incidence of LBW 2.6 units smaller than mothers who have family income $<\mathrm{Rp}$ $1,706,525$.

A study showed that mothers with low family income are 1.4 times more likely to give birth to low birth weight babies than mothers with high family income $(\mathrm{OR}=1.4$; 95\% CI $=1.1-1.8 ; \mathrm{p}<0.001$ ) (Mahumud et al., 2017).

Another study found that mothers with low economic status are at risk of giving birth to babies with low birth weight $(\mathrm{OR}=1.47 ; 95 \% \mathrm{CI}=1.05-2.05 ; \mathrm{p}=0.022$ (Taywade and Pisudde, 2017). Low monthly income means that the mother is four times more likely to give birth to low birth weight babies compared to mothers with high monthly income $(\mathrm{OR}=3.8$; 95\% $\mathrm{CI}=1.54$ 9.41) (Demelash et al., 2015).

\section{The effect of maternal age on the incidence of $\mathbf{L B W}$}

This study indicates that there is an effect of maternal age at pregnancy on the incidence of LBW. Mothers who are $<20$ years old and $\geq 35$ years old when they are pregnant had the possibility (logodd) to experience LBW incidence by 1.9 units greater than mothers who are $\geq \mathbf{2 0}$ years to $<35$ years old when they are pregnant.

A study showed that maternal age $<20$ years or >35 years is directly associated with the incidence of low birth weight infants (Shrestha et al., 2016). Maternal age affects the incidence of low birth weight babies, maternal age <20 years, $\geq 35$ years has the risk of increasing the risk of low birth weight by 1.4 times greater than mothers aged 20-35 years
$(\mathrm{OR}=1.47 ; 95 \% \mathrm{CI}=0.42-5.15 ; \mathrm{p}=0.544)$ (Khayati et al., 2016).

Due to biological factors, such as chromosomal anomalies, older women are at increased risk of chronic diseases such as preeclampsia, diabetes mellitus, hypertension, and heart disease. It requires them to give birth to preterm babies or babies born with intrauterine growth restriction due to poor maternal health (Sutan and Berkat, 2014; Momeni et al., 2017).

\section{The effect of household cigarette smoke exposure on the incidence of LBW}

The results of this study indicate that household cigarette smoke exposure has an effect on the incidence of LBW. Mothers exposed to household cigarette smoke when pregnant have the possibility (logodd) to experience LBW 1.9 units greater than mothers who are not exposed to household cigarette smoke when they were pregnant.

A study also shows that pregnant women who smoke or are exposed to cigarette smoke during pregnancy will affect the baby's birth weight. In female newborns, the mean birth weight was $5.6 \%$ lower when the mother smoked or was exposed to secondhand smoke. Whereas for male newborns, the average birth weight was $6.7 \%$ lower than that of pregnant women who did not smoke or were exposed to secondhand smoke (Witt et al., 2018).

A study conducted by Kataoka et al. in 2018 showed that $13.4 \%$ of pregnant women smoke during pregnancy. There is a significant reduction in birth weight if the mother has the number of cigarettes per day increasing by 6 to 10 cigarettes per day with the birth weight is $320.41 \mathrm{~g}$ (95\% CI= 535.51 to -105.32 ) lower than the babies born to non-smoker mothers. When mother smoke 10 to 40 cigarettes per day, the birth weight is $435.01 \mathrm{~g}$ ( $95 \% \mathrm{CI}=-733.16$ to 136.87) lower than babies born to non- 
smoker mothers. When pregnant women smoke during pregnancy up to 5 cigarettes per day, there is no effect on birth weight $(\mathrm{p}=0.715)$ (Kataoka et al., 2018).

\section{The effect of psychological stress during gestation on the incidence of LBW}

This study indicates that there is an effect of psychological stress during gestation on the incidence of LBW. Mothers who have high stress during pregnancy were more likely (logodd) to experience an incidence of LBW 1.8 units greater than mothers who have low stress during pregnancy.

It is in line with a study conducted by Nurmayanti et al. in 2017, which found that any increase in the mother's biopsychosic stress would reduce birth weight by 1.81 units $(b=-1.81 ; \mathrm{SE}=0.81 ; \mathrm{p}=0.025)$. Stress during pregnancy is one of the risk factors that causes a higher likelihood of low birth weight (Schetter, 2011; Tandu-Umba et al., 2014).

The results of another study on antenatal psychosocial stress using the Curry et al. (1998) questionnaire, namely the Prenatal Psychosocial Profile: Stress Scale questionnaire, stated that $78 \%$ of pregnant women experienced low stress during pregnancy (Woods et al., 2010).

\section{The effect of anemia on the incidence of $\mathbf{L B W}$}

The results show that there is an effect of anemia on the incidence of LBW. Mothers who experience anemia during pregnancy have a probability (logodd) of LBW 3.1 units greater than mothers who do not experience anemia when they are pregnant.

In low and middle-income countries, $42.7 \%$ of women experience anemia during pregnancy. Pregnant women with anemia have a higher risk of giving birth to babies with low birth weight $(\mathrm{RR}=1.31 ; 95 \% \mathrm{CI}=$ 1.13-1.51) (Rahman et al., 2016). Some diseases during pregnancy that cause low birth weight are anemia during pregnancy (Moise et al., 2017).

Other studies have shown anemia during pregnancy is one of the major nutritional disorders with serious short- and long-term consequences for both mother and fetus. Anemic pregnant women increased the risk of low birth weight $(\mathrm{RR}=$ 2.06; $95 \% \mathrm{CI}=1.03$ to 4.11 ) (Zerfu et al., 2016).

7. Effect of nutritional status (maternal MUAC) on the incidence of LBW

This study indicates that there is an effect of nutritional status (MUAC) on the incidence of LBW. During pregnancy, mothers who have MUAC $\geq 23.5 \mathrm{~cm}$ have the possibility (logodd) to experience the incidence of LBW 1.7 units greater than mothers who have MUAC $<23.5 \mathrm{~cm}$ during pregnancy.

The results of other studies that support also stated that mothers who have an upper arm circumference $<23.5 \mathrm{~cm}$ increase the risk of low birth weight babies. There is a direct, statistically significant positive effect of maternal MUAC on birth weight. Thus, mothers with MUAC $<23.5$ $\mathrm{cm}$ have a protective effect on LBW incidence (Khayatiet al., 2016; Yuliati, 2016; Nurmayantiet al., 2017).

\section{AUTHOR CONTRIBUTION}

Isne Susanti was the main researcher who collected the data of the study, formulated articles of the study, and processed data. Harsono Salimo played a role in the formulation of the background. Yulia Lanti Retno Dewi helped in formulating a study framework and discussion.

\section{CONFLICT OF INTEREST}

There is no conflict of interest in this study. 
FUNDING AND SPONSORSHIP

This study used the authors' funds.

\section{ACKNOWLEDGEMENT}

The authors would like to express their gratitude to the Head of the Gunungkidul Regency Health Office, who has helped the researchers in conducting this study and all the respondents who have been willing to help and cooperate during the study.

\section{REFERENCE}

Demelash H, Motbainor A, Nigatu D, Gashaw K, Melese A (2015). Risk factors for low birth weight in Bale zone hospitals, South-East Ethiopia: A casecontrol study. BMC Pregnancy and Childbirth, 15(1): 1-10. https://doi.org/10.1186/s12884-015-0677-y

Dinas Kesehatan DIY (2019). Profil Kesehatan D.I.Y tahun 2018.

Schetter CD (2011). Psychological science on pregnancy: Stress processes, biopsychosocial models, and emerging research issues. Annual Review of Psychology, 62(1): 531-558. https://doi.org/10.1146/anurev.psych.031809.130727

Islam MM, ElSayed MK (2015). Pattern and determinants of birth weight in Oman. Public Health, 129(12): 16181626. https://doi.org/10.1016/j.puhe.2015.07.011

Kataoka MC, Carvalheira APP, Ferrari A P, Malta MB, de Barros Leite Carvalhaes MA, de Lima Parada CMG (2018). Smoking during pregnancy and harm reduction in birth weight: A crosssectional study. BMC Pregnancy and Childbirth, 18(1): 1-10. https://doi.org/10.1186/s12884-018-1694-4.

Kemenkes RI (2015). Accreditation of public health centres, first-line clinics, general practitioners and dentists.

Kementerian Kesehatan RI (2018). Profil
Kesehatan Republik Indonesia Tahun 2017.

Khayati YN, Prayitno A, Pamungkasri EP (2016). Multilevel analysis on the factors associated with low birth weight in Temanggung, Central Java. J Matern Child Health. 01(01): 7-12. https://doi.org/10.26911/thejmch.2016.01.01.02

Yuliati L, Murti B, Sutisna E (2016). Hubungan antara pendidikan, pendapatan keluarga, asupan gizi, pemeriksaan kehamilan, kurang energi kronis dan anemia dengan berat bayi lahir rendah di Kabupaten Gresik. Masters Thesis, Universitas Sebelas Maret. Retrieved from https://eprints.uns.ac.id/id/eprint/25840

Mahumud RA, Sultana M, Sarker AR (2017). Distribution and determinants of low birth weigth in developing countries. Journal of preventive medicine \& public health. 50: 18-28

MoiseKK, Blood BND, René MMJ, PaulCM, Kennedy MN, Brigitte KT, MichelKN (2017). Risk Factors of low birth weight in Mbujimayi City, Democratic Republic of Congo. OALib, 04(03), 110. https://doi.org/10.4236/oalib.1103501.

Momeni M, et al. (2017). Prevalence and risk factors of low birth weight in the southeast of Iran. IJPM e, 8. doi: 10.4103/ijpvm.IJPVM_112_16.

Nurmayanti R, Salimo H, Dewi YLR (2017). Effects of Maternal Nutrition Status, Maternal Education, Maternal Stress, and Family Income on Birthweight and Body Length at Birth in Klaten, Central Java. JMCH, 02(04): 297308. https://doi.org/10.26911/thejmch.2017.02.04.02/

RahmanM, Abe SK, Rahman S, Kanda M, Narita S, Bilano V, Ota E, Gilmour S, Shibuya K (2016). Maternal anemia 
and risk of adverse birth and health outcomes in low- and middle-income countries: systematic review and'. doi: 10.3945/ajcn.115.107896.

Rajashree K, Prashanth H, Revathy R (2015). Study on the factors associated with low birth weight among newborns delivered in a tertiary-care hospital, Shimoga, Karnataka. IJMSPH. 4(9): 1287. doi:10.5455/ijmsph.2015.23032015263.

Riskesdas (2018). Hasil Utama Riskesdas Penyakit Tidak Menular 2018. Hasil Utama Riskesdas Penyakit Tidak Menular.

Sebayang SK, Dibley MJ, Kelly PJ, Shankar AV (2012). Determinants of low birthweight, small-for-gestational-age and preterm birth in Lombok, Indonesia: Analyses of the birthweight cohort of the summit trial. TMIH. 17(8): 938950. doi: $10.1111 / \mathrm{j} .13653156 .2012 .03-$ 039.x

Sutan R, \& Berkat S (2014). Does cultural practice affects neonatal survival- a case control study among low birth weight babies in Aceh Province, Indonesia. BMC Pregnancy and Childbirth, 14(1): 1-13. https://doi.org/10.1186/1471-2393-14-342.

Tandu-Umba B, Dedetemo DK, Mananga GL (2014). Maternal stress and pregnancy outcomes. OJOG, 04(07): 361370. https://doi.org/10.4236/ojog.2014.47054.

Taywade ML, Pisudde PM (2017). Study of sociodemographic determinants of low birth weight in Wardha district, India. Clinical Epidemiology and Global Health, 5(1): 14-20. https://doi.org/10.1016/j.cegh.2016.07.001

Witt SH, Frank J, Gilles M, Lang M, Treutlein J, Streit F, Wolf IAC, Peus V, Scharnholz B, Send TS et al., (2018). Impact on birth weight of maternal smoking throughout pregnancy mediated by DNA methylation. BMC genomics. BMC Genomics, 19(1): 290. doi: 10.1186/s12864-0184652-7.

Woods SM, Melville JL, Guo Y, Fan MY, Gavin A (2010). Psychosocial stress during pregnancy. Am J Obstet Gynecol, 202(1): 61.e1-61.e7. https://doi.org/10.1016/j.ajog.2009.07.041

World Health Organization (2012). World health assembly global nutrition targets 2025: Low birth weight policy brief. WHO, 1-7. Retrieved from .http://www.who.int/nutrition/topics/globaltargets_stunting_policybrief.pdf

Zerfu TA, Umeta M, Baye K (2016). Dietary diversity during pregnancy is associated with reduced risk of maternal anemia, preterm delivery, and low birth weight in a prospective cohort study in rural Ethiopia. (1): 14821488. doi: 10.3945/ajcn.115.116798. 